\title{
Servant leadership and shepherd leadership: The missing dynamic in pastoral integrity in South Africa today
}

Author:
Kelebogile T. Resane ${ }^{1}$
Affiliation:
'Department of Historical
and Constructive Theology,
Faculty of Theology
and Religion, University of
the Free State, Bloemfontein,
South Africa
Corresponding author:
Kelebogile Resane,
resanekt@ufs.ac.za
Dates:
Received: 10 June 2019
Accepted: 24 Jan. 2020
Published: 12 Mar. 2020
to read online or
How to cite this article:
Resane, K.T., 2020, 'Servant
leadership and shepherd
leadership: The missing
dynamic in pastoral integrity
in South Africa today',
HTS Teologiese Studies/
Theological Studies $76(1)$,
a5608. https://doi.org/
10.4102/hts.v76i1.5608
Copyright:
@ 2020. The Authors.
Licensee: AOSIS. This work
is licensed under the
Creative Commons
Attribution License.

This article aims to give a full definition of servant leadership and shepherd leadership by comparing and contrasting the two texts of Jeremiah 23 and John 10. The notion of 'shepherd' or 'shepherding' is analysed and brought into the current debate on servant leadership. The shepherd metaphor used in the two passages is contextualised to the South African pastoral leadership situation, especially with regard to pastoral integrity. The status of pastoral leadership in the South African church community is highlighted as a challenge to be considered from the perspective of servant leadership proposed in Matthew 20:16. The presenter would like to conscientise the Christian community that integrity in the areas of caring, feeding and protecting the flock should be a driving force towards pastoral integrity. The exegetical findings of the shepherd model are applied to the pastoral leadership integrity. An appeal is made to the ecclesiastical community to return to the fundamentals of leadership by embracing servant leadership as an ensuing model for pastoral leadership integrity. The article contributes towards the knowledge of the definition, role and understanding of pastoral leadership defined through servant and shepherd leadership concepts. Its academic value lies in the fields of church leaderships, ethics and biblical teachings.

Keywords: servant; shepherd; leader; pastor; church; integrity.

\section{Introduction}

This article defines the concepts of servant leadership and shepherd leadership; it aims to explain how these two leadership concepts express leadership in the church, especially for those in pastoral leadership. The three texts of Jeremiah 23, John 10 and Matthew 20:16 are briefly surveyed to define these two leadership concepts. It has to be borne in mind that there is currently no theological in-depth analysis of these concepts, except gleaning from the fields of psychology and sociology, with a little bit of contribution from practical theology. It is broadly accepted that theology cannot be a mere observer of developments in other disciplines, especially in humanities, without formulating its own theoretical frameworks in and through which to conduct its arguments and insulate key ideas from these external sceptics and mystics (Lovin et al. 2017:xxi). This gives this article the authenticity of interdisciplinarity and shows how social sciences are symbiotically related to expose the truth that supports or enhances metanarratives.

Pastoral leadership in South Africa is, in many instances, marred by integrity crises. Proposal brought forth is the warning against materialism, lack of credibility in reporting, pride and shallow theological training.

These could be addressed with credible pastoral theology that emphasises pastoral ethics, which focus on training that does not separate the academic from the practical exposure and experience. This is in agreement with Chiroma (2017) that:

Ministerial development is to be holistic, including the personal, spiritual, academic and social development of students. Effective ministry requires not only abstract theological and biblical knowledge, but also a certain level of ministerial competencies (e.g. the articulation of theological reflection and learning the practice of ministry, the transition from formal theological training into the work of ministry). (p. 51)

The curriculum for ministerial training and formation is challenged to take a new turn where morality and integrity form an irrefutable salience in the development of servant and shepherd leaders. 


\section{Definitions of terms}

\section{Servant leadership}

Servant leadership is a timeless leadership philosophy with its main focus on a leader as a servant whose purpose is to serve. The servant leadership philosophy and practices have been expressed in many ways and applied in many contexts. Some of the most well-known advocates of servant leadership philosophy include Blanchard $(2003,2007)$ Stephen Covey, Merrill \& Merrill (1995), Senge (1990), Peck (2004), Wheatley (2002), McGee-Cooper, Welch and Trammell (2015), Spears (2010:16) and Keith (2015) from the Greenleaf Center for Servant Leadership. The phrase 'servant leadership' was coined by Robert K. Greenleaf in The Servant as Leader, an essay that he first published in 1970. In that essay, Greenleaf said:

The servant-leader is servant first ... It begins with the natural feeling that one wants to serve, to serve first. Then conscious choice brings one to aspire to lead. That person is sharply different from one who is leader first, perhaps because of the need to assuage an unusual power drive or to acquire material possessions ... The leader-first and the servant-first are two extreme types. Between them there are shadings and blends that are part of the infinite variety of human nature.

Quite a good number of authors mentioned above are associated with Greenleaf Center for Servant Leadership based in Indianapolis, IN, USA. For instance, in his works, Greenleaf discusses the need for a better approach to leadership, one that puts serving others - including employees, customers and the community - as the number one priority. Servant leadership emphasises increased service to others, a holistic approach to work, promoting a sense of community and the sharing of power in decision-making (Spears 2005:2). Spears (2005) continues to highlight that in all of Greenleaf's writings, there are 10 characteristics of the servant-leader that are of critical importance and are central to the development of servant-leaders. Without any elaboration on each of them, these characteristics are: listening, sympathy, healing, awareness, persuasion, conceptualisation, foresight, stewardship, commitment to the growth of people and building of the community (Spears 2005:3-4). One exponent of servant leadership is Wong (2007), who continued the notion as follows:

In sum, different from the traditional trait, behavioral, situational, and contingency leadership models, SL focuses on (a) the humble and ethical use of power as a servant leader, (b) cultivating a genuine relationship between leaders and followers, and (c) creating a supportive and positive work environment. However, in terms of the actual exercise of leadership, servant leaders are free to incorporate the positive aspects of all other leadership models except command-and-control dictatorship. (p. 3)

The bottom line of this servant-first is to ensure that other people's highest priority needs are being served.

The ensuing passion of servant leadership is the growth of those being served. In this process of being served, the measuring yardstick assesses how those being served grow wiser, become freer, healthier and become the initiators rather than those commanded. A servant-leader focusses primarily on the growth and the well-being of people and the communities to which they belong. Whilst traditional leadership generally involves the accumulation and exercise of power by one at the 'top of the pyramid', servant leadership is different. The servant-leader shares power, places the needs of others first and helps people develop and perform as efficiently as possible.

In his second major essay, The Institution as Servant, Greenleaf articulated what is often called the 'credo'. There he said the following (Spears 2004):

This is my thesis: caring for persons, the more able and the less able serving each other, is the rock upon which a good society is built. Whereas, until recently, caring was largely person to person, now most of it is mediated through institutions - often large, complex, powerful, impersonal; not always competent; sometimes corrupt. If a better society is to be built, one that is more just and more loving, one that provides greater creative opportunity for its people, then the most open course is to raise both the capacity to serve and the very performance as servant of existing major institutions by new regenerative forces operating within them. (p. 7)

Servant leadership is easy for people with high self-esteem. Such people have no problem giving credit to others. They have no problem listening to other people for ideas. They have no problem in nurturing other people towards maturity and competency. They do not think that building up other people is going to be threatening in any way (Blanchard 1999:2). For them, empowering other people is a goal, for they know that once 'the conditions of empowerment are in place, servant leadership creates powerful results' (Covey, Merril \& Merril 1995:251). In a nutshell, servant leadership is a process of influencing others to confront reality and move towards a shared vision, whereby the interests of people and their common good are prioritised over the personal interests of the leader (Ebener 2010).

\section{Shepherd leadership}

Shepherd leadership is sending others to the front to take the lead in areas where they are the strongest. It is both a quality and the action of deliberate efforts to develop others. It is a leadership sense of responsibility entrusted by God to map out the way for a brighter and better future for the emerging leaders. The welfare of the sheep (those led) becomes a priority. The present author (Resane 2014) mentioned somewhere the following:

[A] shepherd refers to a keeper of sheep. This is the person who tends, feeds, or guards the flocks. The Hebrew word for shepherding is often translated as 'feeding' as it is impressed by the next statement, 'I shall not want' or 'I shall lack nothing' alluding to the fact that the Psalmist means he will lack neither in this life nor in the next. (p. 5)

Shepherd imagery appeared throughout the Bible beginning in Genesis (Stanley 1961), and according to Swalm (2010), shepherding occurred over 500 times across the Old Testament and the New Testament. The great Old Testament leaders, Moses and David, were shepherds of both sheep and 
God's chosen people, whilst many of the Old Testament prophets also used the shepherd imagery as they proclaimed their revelations.

The shepherd metaphor reflects how leaders guide, protect and provide. Resane (2014) expanded this function as follows:

The broader functions of the shepherd were to lead the sheep to pastures and water (Ps 23:1) to protect them from wild animals (1 Sm 17:34-35); and to guard them at night, whether in the open (Lk 2:8) or in sheepfolds (Zph 2:6) where they counted them as they entered the fold (Jr 33:13). They took care of the sheep and even carried weak lambs in their arms (Is 40:11). (p. 2)

This means that the shepherd-leader directs the flock in areas of conduct and actions. They assist or lead the flock. The shepherd teaches the flock for restoration purposes and guides them in paths of righteousness. They are protected from erroneous dogma. Tenney (1975) highlighted this as follows:

The life of the sheep was dependent upon the power and provision of the shepherd. Their recognition of him and his recognition of them established the relationship. Hearing his voice, following his leading, entering the fold through him, and the refusal to follow others was John's picture of belief. (p. 165)

Leaders in the church are called to be shepherds, not a board of directors. This requires involvement in a personal shepherding ministry amongst the people. The shepherd leader unpacks the four primary ministries of shepherds - knowing, feeding, leading and protecting - on macro (church-wide) and micro (personal) levels (Witmer 2010).

The prophetic literature of the Old Testament refers to national leaders as shepherds (Ezk 34:1; Jr 23:1).

Passage from Jeremiah 23 issues judgement to shepherds who have not upheld their duties to their flock. Jeremiah is not concerned with the actual livestock and the real shepherds. Instead, the prophet is using a common metaphor from the ancient Near East to speak of human kings and leaders as shepherds to the people. The ovine imagery is appropriate as the duties and responsibilities of shepherds would be well known to ancient readers.

Shepherds are supposed to take care of their sheep - feed them, protect them and guide them.

When David confronted Goliath, he based his offer primarily on the experience he had gained as a shepherd with lions and bears that preyed on the flock. Shepherding of those days called for bravery, and the shepherd was responsible for the livelihood of the flock. The legitimate shepherd would risk his life for the protection of his flock of sheep. 'The shepherd willingly provides for the sheep green grass, safe and secure water, and a safe and protected path' (Adamo 2018:2).

Many pastors do not have intimate knowledge of these pastoral responsibilities. The metaphor of a shepherd really works only for those possessing prior biblical knowledge or livestock lifestyle or experience. How might we reimagine this metaphor for today? How do we speak of and imagine leadership? Similarly, many of us do not live under the rule of a king. To conceive of God as a king does not resonate well with a people of democracy. We need perhaps new metaphors for leadership, a way to update and expand our biblical metaphors. But where shall we obtain these understandings of leadership?

\section{Jeremiah 23 and John 10 narratives examined and compared}

The Jeremiah text shows that the scattering God is also the gathering God. Judgement is passed on the wicked political and religious leaders (kings and shepherds) because they consort and confer together for the scattering and the destruction of God's sheep (Jr 23:1-2), instead of offering pastoral care expected from them. Wessels (2014) is correct that:

In the Jeremiah text the metaphor of a shepherd is used to refer to the leaders in the Judean society (Jr 3:15; 6:3; 10:21; 12:10; 22:22; $23: 1 ; 23: 4 ; 25: 34-36)$. The concept of a shepherd comes from the domain of rustic life where a person is given the responsibility to lead sheep into pastures, to watch over them, to keep them together, to protect them and to bring them back to safety. (p. 2)

The shepherds failed to attend to God's people in care and protection, so God will attend to them on judgement. Not only that, in Jeremiah 23:3-4, God declared:

Then I will gather the remnant of my flock out of all the countries where I have driven them, and I will bring them back to their fold, and they shall be fruitful and multiply. I will set shepherds over them who will care for them, and they shall fear no more, nor be dismayed, neither shall any be missing, declares the Lord.

The Lord will restore the fortunes of his people, and they will have shepherds who care for them, provide for them and protect them. How will these shepherds serve God's people? The parallel passage in Jeremiah 3:15 tells us: And I will give you shepherds after my own heart, who will feed you with knowledge and understanding.

The fallible shepherds (Jr 23:1) will be replaced with credible ones that are divinely appointed to tend the re-gathered sheep (Jr 23:4). The leaders of God's regathered people will lead them by feeding them the knowledge and understanding of God's ways and of the Word.

Unlike the shepherds of Jeremiah 23, Jesus sets an opposite example of what a credible and genuine shepherd should be. The Gospel of John contributed not only unique perspectives on Jesus, his deity and his ministry but also gave an insight into the characteristics necessary to be effective disciples (DeSilva 2004:391). The good shepherd narrative of John 10:1-18 offered unique insights on lessons in leadership directly from Jesus. In fact, John 10 narrative is a Christocentric theology of leadership. Jesus was the epitome of servant leadership, as demonstrated by shepherd-leadership in this narrative (Thompson 2007:117). 
John's Christology provided some unique contributions to the 'identity and significance of Jesus' (DeSilva 2004:417), and the shepherd narrative depicted characteristics of a good shepherd, the leader who protected, guided and cared for the flock. John was clear in presenting Jesus as the 'good shepherd' in John 10 (Scott 1995) who was sacrificial and loving (Wright 2012). Jesus claimed that he was destined to lead the sheep out into new pastures. This, as per David's Psalm 23, meant sustenance and refreshment of the human soul (Tenney 1975:164). The prevalence of shepherding in Scripture suggests that the several aspects of herding and caring for sheep are useful for depicting proper relationships between Christ and his people, and that those characteristics can similarly offer lessons in leadership (Tenney 1981).

The panoramic view of these two texts (Jr 23 and Jn 10) makes one to conclude that the servant leader and shepherd leader share the same characteristics of serving the sheep by loving them and developing a close and intimate relationship with them, so that they know his voice and trust him. This leads to an understanding of the needs of the sheep and what threatens them during their timid state of needs. Servant and shepherd leaders work tirelessly to provide for and protect the sheep by leading them to fresh pastures and fresh water. Generally, this leader cares for, loves and sacrifices his life for them.

The shepherds referred to in Jeremiah's text were those who Jesus called thieves and robbers. Thieves are those who obtain their booty by subtlety, whilst robbers obtain their loot by violence. Thieves come to satisfy their own fleshly desires (Hobbs 1979:50). From Jesus' perspective, these are the false messiahs, false prophets and false teachers.

\section{Pastoral integrity}

Integrity speaks of wholeness, entireness or completeness. The word 'integrity' is derived from the root, integer, which means untouched, intact or entire. Dividedness is not compatible with integrity. A person with integrity is not divided (duplicity) or pretending (hypocrisy). His or her whole life operates in synchrony. He or she is whole and his or her life is put together. All aspects of his or her life work together harmoniously (Wiersbe 1991:21).

Pastoral integrity implies transparency - nothing to hide and nothing to fear. The ethical pastor's life is an open book. He is integer. The person with integrity has a single will that is seeking nothing but to serve others.

Like the shepherds referred to in Jeremiah 23, many pastors in the current South Africa have become blind to the holiness and character of God. Morality has declined in national affairs. It is true that morality declines when a society rejects God. Rejection of God leads to perversion of morality (Klautke 2012:104). Pastoral ethics are at stake as can be borne out by character flaws and questionable actions of many pastors in the public domain.

It is regrettable that many pastors (shepherds) in South Africa carry a marred image regarding pastoral integrity, and
Christian values, as expounded by the Christian canon. Their actions are divorced from their character. They carry charisma without character (Resane 2018):

Leaders of the cloth are expected to combine theoria and praxis. Pastoral leaders must be trained to think ethically and to act morally. This may lead to victory par excellence. On the same tangent, gist and self-discipline (character) should synchronise in order to foster conviction. Conquering the world starts with conquering the self. (p. 349)

The shepherds encountered in the Jeremian text are the false prophets who resembled covetous leaders who used religion for personal gain. Their lives were surrounded with pashhur [prosperity] in and through religion, and civil affairs. In this situation, social justice is impossible, as the rich make themselves richer at the expense of the poor.

A secular culture, together with its values, has affected the church more than the church has affected it. The country with over $70 \%$ population claiming to be Christians is infested with criminal acts such as human abuse (rape, homophobia, xenophobia), disrespect for fellow citizens (robbery, housebreaking, car hijacking, etc.) and corruption at high places (politics, church, business). Corruption permeates all spheres of society to destabilise societal harmony and environmental solidity (De Wet \& Kruger 2013):

Corruption's bane does not only lie in a destructive socioeconomic environment with elements like poverty, crime and displacement as its symptoms. It also corrupts the core of human relationships, value systems and vision of life. (p. 1)

Four specific areas have been especially alluring to those whom God has called to the ministry.

1. Materialism is fast replacing the authenticity of the gospel and integrity in theology and conduct. By definition, materialism is a tendency to consider material possessions and physical comfort as more important than spiritual values. It is the belief that having money and possessions is the most important thing in life. For some South African pastors, especially those in the camp of 'health and wealth' gospel, motives of doing ministry are driven not by God but by gold. Silver and self-interest instead of the Saviour has become the motivating factors for ministry. This has become known as commercialisation of the gospel or of theology. Commercialisation of theology is broadly defined as what, how and why the Christian ministry is undertaken (Resane 2017:2). McQuilkin (1988:358-362) referred to this as the unscrupulous methods of gaining funds through common deception, 'bait and switch', psychological manipulation and/or asking money in exchange of any item that may bring charm, luck or success of any sort.

Sadly, too many of God's ministers view themselves as corporate chief executive officers (CEO) rather than shepherd-servants or pastor-teachers of his flock. They lose personal perspective and usually find themselves pursuing worldly desires and spending less and less time 
with God's flock, including their spouses and families. The fallout has been tragic and devastating. In a businessorientated society, everything is for sale. In order to gain financially under the guise of serving the community, the church commercialised its product. The message is packaged in variable forms: books, compact discs, digital versatile discs, live streaming, etc. (Beyers 2015:6).

2. The three P's (power, position and prestige) that lead to the second cause of pastoral integrity crisis is egotism or pride. Personal power, position and prestige are often justified by sanctimonious desire for bigger and better ministries. The canonical teaching is that God always opposes pride in any form (Ja 4:6-10). The pastoral motive that pursues pastoral integrity sacrificially cares and guards the sheep and the church given under their oversight.

3. False reporting and exaggeration of accomplishments, accompanied by lying, tarnishes pastoral integrity and image. Blowing and fudging the statistics is nothing else but falsehood with a high and an inevitable cost to pastoral integrity. Pastoral respect is built on the solid foundation of truthful behaviour and honest speech $(\operatorname{Pr} 6: 16,19)$.

The credibility of our integrity is tested by our reporting mechanisms. Pastors are worried about numbers to such an extent that it has become a norm for some to substitute statistical records for spiritual reality. Many pastoral conferences and seminars are clouded with questions such as:

a. How many attended?

b. How many made the decisions?

c. How many took up membership?

d. How much was the offerings or tithes?

Names and numbers have become a church, instead of her becoming an assembly of the redeemed and the faithful. There is nothing wrong with numbers, but they must not drive pastoral integrity.

There is a significant difference between knowing the number of the sheep and knowing the state of the flock. The good shepherd is concerned about even one sheep that has strayed away (Wiersbe 1991:45):

4. Shallow theology and false ideas derived from popular literature twist genuine spirituality and lead to the failure of the pastoral integrity and ministry. It is important for pastors-in-training to receive theologically sound content that leads to life transparency, reflecting the character of Christ (Resane 2018):

The moral conservatism or legalistic dictates on teaching and learning environment are powerful tools of the hidden curriculum. The legalism students imbibe at the college can easily be transported to the church life that the graduate will be teaching. (p. 8)

Shallow and a very narrow theology reduces the Christian faith to a private and personal concern of individuals and separates them from the needs and concerns of the wider society in which the flock resides (Kretzschmar 1997:313).
Just as the shepherd leads the sheep to the green grass and fresh waters, so should the pastor dwell on biblical exposition to nurture the church with adolos [unadulterated] milk that should create more yearning or craving (epipothein) for more. Personal holiness and sacrifice are the hallmarks of the dedicated pastors who pursue integrity of the divine calling upon their lives. Many South African churches are led by shepherds who aim for 'feel good' sermons that are not biblically based and carry no biblical substance. As a result, the biblical instruction becomes anaemic, either overemphasising legalism or emotionalism. Fruitlessness ensues or quality of spirituality becomes compromised, as ethics are not central to shepherding activities. Kretzschmar (2011) correctly pointed out:

Ethics, when rooted in spirituality, bears fruit such as the ability to understand and evaluate one's self and one's context, and to be motivated to be transformed and to act as an agent of transformation alongside others. (p. 69)

Once a shepherd/pastor is consumed with a desire for more in one area (e.g. materialism), it often leads to desire for more in another (sex). One evangelical writer, Wiersbe (1991:105) has noted that pride, money and sex are the enemy's chief weapons for ruining a ministry, and often they work together. When a man deceives himself into thinking that he deserves and is entitled to the power, position and prestige that often accompany a successful ministry, he may also deceive himself into thinking that accessibility and entitlement to a liaison with a woman other than his wife is his option, maybe even his right. Finally, and most importantly, if a pastor is dishonest in one area of life (lying and exaggerating accomplishments), he is likely to be dishonest in other areas, including faithfulness to the spouse and ultimately faithfulness to Saviour, the shepherd and the bishop of our souls (1 Pt 2:25). This inevitably puts pastoral integrity under scrutiny. Wearing a façade is the worst hypocrisy. Pastors who pursue integrity become part of the church and walk together in the light with the church members. Bruinsma (2015) is worth quoting here:

We will not be effective preachers if we sit in our ivory palaces and do not enter into the life of the sheep. They must be able to see us as one with them. They must see us as a friend. Not just a dominie (lord), but a friend. They must hear us speak of our need for Christ and the joy we receive in our salvation. They must see in us a humble admission that we too are sinners. We are no different than they are. When we become a part of the life of the church, then we will see firsthand the needs of God's sheep. We will be able to take God's Word and bring it to them as one that they know is applying that Word to himself just as well as he is applying it to them. (p. 10)

\section{Servant leadership in Matthian text (20:16)}

The last labourers into the field were the first to be called in for their wages. They received the same share like the ones who entered the field earlier. Justice was shared proportionately. Promises were fulfilled to all who were invited. The context is that the Jews, who are the progenitors of salvation, will be shocked to realise that the late arrivals, the Gentiles, will 
receive the same treatment like them from God. The parable was the answer to Peter's question in Matthew 19:27 - 'what then will there be for us?' Christ answers by explaining that disciples are to fulfil the task entrusted to them, leaving the distribution of rewards to him.

The parable encourages faithfulness, for those called into the ministry (Pentecost 1982):

$[M]$ ay graciously receive a reward equal to that received by those who were first called to Christ as His labourers and who endured so much suffering and even death for His name's sake. (p. 124)

God cares for people more than for things. 'The owner was not thinking of profit. He was thinking of people, and he was using his abundant means to help them' (Boice 1983:63). This is what is expected from the shepherd who out of abundance of capacity goes all out for the welfare of the sheep. 'Service of others, not profit for self, must be the Christian principle' (Barclay 1999:167). Servant leadership is taking people's interests to heart and thinking on how to address them.

Unlike the selfish shepherds of Jeremiah 23, the owner of the vineyard is generous with his possessions and shares them with those in need. Like Jesus in John 10, he keeps his eye on the sheep in order to discern their needs.

The unemployed, who almost gave up hope towards the end of the day, were rescued by being given a short chance to relieve their destitution. It is never too late to regain sanity, especially in leadership situation, where one has lost integrity. The godless world is in destitution, where people wander like sheep without a shepherd.

They are the naïve sheep - infants that are tossed back and forth by the waves, and blown here and there by every wind of teaching and by the cunning and craftiness of people in their deceitful scheming (Eph 4:14).

\section{Solution: Pastoral integrity restored through proper pastoral theology}

Pastoral theology explores the rationale, nature and ethos of care in the community of faith. In a broader scope, it can be said that it is a reflective practice of love and service activities. Pastoral theology is an attempt at enfleshing and refining acts of love and care engaged in an expression of faith - a reflection on the caring activities of God and communities. The pastor in this regard accounts, records, recounts experiences and believes in the ways that God cares and the caring activities of the community.

Pastoral theology, which is so very necessary for the restoration of pastoral integrity, should be critical and constructive, interpretive and expressive. Its focus is on care, with the intention of enacting transformative healing. This calls for the overhaul of the pastoral theology curriculum. Pastoral training needs some revolutionary dynamism so that the trainees can grasp the importance of integrity as the central culture of pastoral calling. The present author fully agrees with Naidoo (2016) that:

Contemporary voices call on theology to become more contextual, practical or relevant rather than being a highly theoretical discipline, with a growing distance between the academy and the local church. (p. 5)

Pastoral education should always have three fundamental objectives. These are: (1) ministerial formation; (2) spiritual/ personal formation; and (3) academic formation. In following the learning theory known as Bloom's Taxonomy, the objectives must be expressed in and through hands, heart and head. In the first and the second objective, the application is that of Christian standards. In the third objective, the application is that of the standards of the world. Pastoral training should never separate the academic from the practical, the head from the hands and leave the heart to the peripheral lifestyle. Resane (2018a) pointed to this as follows:

There is some symbiotic relationship between ministerial formation and moral formation. Knowledge comes through information, and that may lead to transformation. (p. 354)

Traditionally, pastors' trainers embraced the dictum: 'get the theology right and the conduct will follow', although it often does not. Liberation theology inclines itself to the opposite: 'get the conduct right and the theology will follow'. It is critical to balance knowledge with practice, otherwise what is transmitted is no more education but some form of fallacy. Naidoo (2010) made the following appeal:

Teaching practices are the fundamental processes by which we learn and become who we are. Pedagogies of formation involve the integrated development of knowledge and spirituality, identity and integrity in the professional formation of clergy. Pedagogies of contextualisation have to do with grounding pedagogies of formation in the interplay of historical and contemporary contextual influences. (pp. 347-348)

Pastors and theologians today are more aware of the need to 'do' theology, to let the Word speak into the context in which theology is practiced. Many scholars in the field of theology are exploring global theology that relates to contemporary scientific, postmodern and religious thought, as people are thinking and debating today. Teaching and forming students of theology in institutions have a similar but additional task - to relate theology to the people's taught. This calls for balance that Naidoo (2010) is concerned about:

The training of ministers involves the cognitive acquisition of appropriate knowledge, competence in required ministerial skill and personal character development. (p. 349)

Graham (2002:228-236) correctly stressed that the overall aim of theological education should be the development of theological learning; practical preparation for ministry; spiritual and ministerial formation; and growth in personal maturity. Issues of character, lifestyle, integrity and godliness must form part of the ingredients of the aims of theological education. Student pastors must be taught how to integrate belief, behaviour, right thinking and right living. 
Pastors should be the people with integrity, the people who have leadership skills and the people who have a vision for the ministerial calling they are undertaking. They need to have fresh ideas to deal with old challenges (conservatism and legalism), and they should be willing to do the hard work it will take to rebuild the church in South Africa. Pastors who walk with integrity are those who opened their lives to the crucified and the risen Lord in order to become the people God wants them to be, to care for those closest to them. They participate in God's kingdom dream for a healed and a healing community. Their integrity is noticed in and through the message they deliver, and with a special love to bestow. Engagement with the task to which God calls them brings them alive, releases locked-up potential and gives real fulfilment (Hudson 2007:112-114).

\section{Conclusion}

Pastoral integrity is one of the missing dynamics in the leadership of many South African churches of today. There is a critical concern for the return to servant and shepherd leaderships. These two leadership styles are not operating in tangents but as some form of symbiosis. Servant leadership ensures that other people's highest priority needs are being served. The ensuing passion of servant leadership is the growth of those being served. It is identifying and reaching people at their point of need. A good example is the owner of the vineyard who saw that the people were in need of employment, and generously lent a helping hand for them to meet their needs, regardless of the length of time they served him. Servant leadership is more of how much can I put in to uplift someone in need. It is creating an opportunity for others to lead in order so that they may grow.

On the other hand, shepherd leadership is driven by caring, feeding, guarding and providing for those one leads. It is sending others to the front to lead from their strength. It is both a quality and the action of deliberate efforts to develop others. It is a leadership sense of responsibility entrusted by God to map out the way for a brighter and better future for the emerging leaders.

The two leadership styles are to be carried with pastoral integrity, which is not governed by materialism, pride, false reporting and shallowness in theological understanding. The attitude of servanthood and shepherding is when a shepherd or a pastor humbles himself in order to serve - to become the last instead of the first.

Solution proposed here one of credible pastoral theology, which should be balanced academically and practically. It should be the theology of 'do' and 'live'.

It is the theology that explores the rationale, nature and ethos of care in the community of faith. It is a reflective practice of love and service activities. In diverse components, it is a theology that is couched in the metanarratives and the context where it is practised. 'This calls for a pastor who understands culture, religious beliefs, contextual variables, church dogma, local laws and human rights' (Moyo 2015:25).
Reading through this article, one concludes with paraphrased assertion of Moyo (2015:24-25) that the pastor is a shepherd who is a visionary so that the sheep cannot be lost, stolen, abused, oppressed or starved to death because of the lack of green pastures. A pastor communicates with the sheep - the people gifted with wisdom to know their needs, joys and hopes. Jesus, the chief shepherd, laid out an example that shepherds (pastors) must cross the cultural barriers to reach out to the marginalised people, feed the hungry and heal the broken-hearted. The shepherd must know the sheep and the sheep must know the shepherd. In this case, leadership means leading by example, walking the talk and allowing the flock (congregation) to learn from the lifestyle of the pastor.

Pastoral care for spiritual needs promotes progress, development and success of good endeavours by the flock. Indeed, according to Moya (2015):

Servant leadership is key in pastoral leadership. Jesus says the one who wants to be the greatest amongst the disciples must be the least ... Servant leadership is leadership that serves the needs of the sheep by shelving sacrificially one's own needs. (pp. 26-27)

Although, there is abundance of literature on servant leadership, it is mostly encased in either popular or secular literature. However, it can be theologically legitimate that both servant leadership and shepherd leadership can be located in religious and theological fields. If one considers the root meaning of religion, which is religio, meaning 'to rebind', then one is led to conclude that servant leadership is a religious or theological concept of leadership. Greenleaf (in Spears 2002:231) correctly asserted that: 'the thing to be done with religious concern is to rebind humankind to the cosmos, to heal the pervasive alienation'. This is servant leadership sans peuret sans reproche (without fear and without reproach).

\section{Acknowledgements Competing interests}

The author has declared that no competing interests exist.

\section{Author's contributions}

The author declares that he is the sole author of this research article.

\section{Ethical consideration}

This article followed all ethical standards for a research without direct contact with human or animal subjects.

\section{Funding information}

This research received no specific grant from any funding agency in the public, commercial or not-for-profit sectors.

\section{Data availability statement}

Data sharing is not applicable to this article as no new data were created or analysed in this study. 


\section{Disclaimer}

The views and opinions expressed in this article are those of the author and do not necessarily reflect the official policy or position of any affiliated agency of the author.

\section{References}

Adamo, D.T., 2018, 'Reading Psalm 23 in African context', Verbum et Ecclesia 39(1), a1783. https://doi.org/10.4102/ve.v39i1.1783

Barclay, W., 1999, The parables of Jesus, Westminster John Knox Press, Louisville, KY.

Beyers, J., 2015, 'Self secularisation as challenge to the church', HTS Teologiese Studies/ Theological Studies 71(3), Art.\# 3178. https://doi.org/10.4102/hts.v71i3.3178

Blanchard, K., 1999, 'Today's successful managers are more like cheerleaders than critics', The Blanchard Management Report, Positive Living, March/April 1999, Peale Center for Christian Living, viewed 23 May 2019, from https://www. guidepostsbooks.com/.

Blanchard, K., 2003, The servant leader: Transforming your heart, head, hands and habits, Thomas Nelson Publishers, Nashville, TN

Blanchard, K., 2007, The heart of a leader, 2nd edn., David C Cook, Colorado Springs, CO. Boice, J.M., 1983, The parables of Jesus, Moody, Chicago, IL.

Bruinsma, W., 2015, April, 'The minister's development of his preaching after seminary', Protestant Reformed Theological Journal 48(2), 3-10.

Chiroma, N., 2017, 'Mentoring and the ministerial formation of seminary students', Stellenbosch Theological Journal 3(1), 51-68. https://doi.org/10.17570/stj.2017. v3n1.a03.

Covey, S.R., Merril, A.R. \& Merril, R.R., 1995, First things first: To live, to love, to learn, to leave a legacy, Simon \& Schuster, New York.

DeSilva, D.A., 2004, An introduction to the New Testament: Contexts, methods, and ministry, Apollos, Nottingham.

De Wet, F.W. \& Kruger, F.P., 2013, 'Blessed are those that hunger and thirst for righteousness: Sharpening the ethical dimension of prophetic preaching in context of corruption', Verbum et Ecclesia 34(1), Art. \#722. https://doi.org/ 10.4102/ve.v34i1.722

Ebener, D.R., 2010, Servant leadership models for your Parish, Paulist Press, Mahwah, NJ.

Graham, S.L., 2002, 'Theological formation on the web: A case study in formation for ministry', Teaching Theology and Religion 5(4), 228-236. https://doi.org/ 10.1111/1467-9647.00142

Hobbs, H.H., 1979, John: A study guide commentary, Zondervan Publishing House, Grand Rapids, MI.

Hudson, T., 2007, Signposts to spirituality: Towards closer walk with God, Struik Christian Books, Cape Town.

Keith, K.M., 2015, The case for servant leadership, The Greenleaf Center for Servant Leadership, Indianapolis, IN.

Klautke, J.-B., 2012, April, 'Challenges for Christian ethics in light of contemporary development in western society', Protestant Reformed Theological Journal 45(2), 103-124.

Kretzschmar, L., 1997, 'The gap between belief and action: Why is it that Christians do not practise what they preach?' Scriptura 62(1997), 311-321. https://doi.org/ not practise what th

Kretzschmar, L., 2011, 'Can morality be taught? A reflection on teaching theological ethics at a tertiary level in the Unisa open and distance learning model', Journal of Theology for Southern Africa 141, 61-80.

Lovin, R.W., Danchin, P., Fuentes, A., Nüssel, F. \& Pope, S., 2017, 'The virtues of humility and hope', in R.W. Lovin \& J. Mauldin (eds.),Theology as interdisciplinary inquiry: Learning with and from the natural and human sciences, pp. xiii-xxxiii, W.M Eerdmans, Grand Rapids, MI.

McGee-Cooper, A., Welch, D. \& Trammel, D., 2015, The art of coaching for servant leadership: A guide for coaches, managers, and anyone who wants to bring out the best in others, CreateSpace Independent Publishing, Scotts Valley, CA.
McQuilkin, R., 1988, An introduction to biblical ethics, class notes for Biblical ethics, Columbia Bible College and Seminary, Columbia, SC.

Moyo, H., 2015, 'The pastor and the embryonic pastoral identities in Southern Africa in the 21st century', in H. Moyo (ed.), Pastoral care in a globalised world: African and European perspectives, pp. 13-37, Cluster Publications, Pietermaritzburg.

Naidoo, M., 2010, November, 'Ministerial training: The need for pedagogies of formation and of contextualisation in theological education', Missionalia 38(3), 347-368.

Naidoo, M., 2016, 'Overcoming alienation in Africanising theological education', HTS Teologiese Studies/Theological Studies 72(1), Art.\# 3062. https://doi.org/10.4102/ hts.v72i1.3062

Peck, M.S., 2004, The road less travelled, 25th anniversary edition: A new psychology of love, traditional values, and spiritual growth, Touchstone, New York.

Pentecost, J.D., 1982, The parables of Jesus, Kregel Publications, Grand Rapids, MI.

Resane, K.T., 2014, 'Leadership for the church: The shepherd model', HTS Teologiese Studies/Theological Studies 70(1), Art.\# 2045. https://doi.org/10.4102/hts.v70i1.2045

Resane, K.T., 2017, 'Commercialisation of theological education as a challenge in the neo-Pentecostal charismatic churches', HTS Teologiese Studies/Theological Studies 73(3), a4548. https://doi. org/10.4102/hts.v73i3.4548

Resane, K.T., 2018, 'Marital fidelity and chastity: The missing ethology in charismatic pastoral leadership', Stellenbosch Theological Journal 4(1), 347-366, https://doi. org/10.17570/stj.2018.v4n1.a16

Scott, J.J., 1995, Jewish backgrounds of the New Testament, Baker Books, Grand Rapids, MI.

Senge, P., 1990, 'The leader's new work: Building learning organizations', Sloan Management Review 32(1), 7-23.

Spears, L.C., 2002, Servant leadership: A journey into the nature of legitimate power and greatness (essays by Robert K Greenleaf), Paulist Press, New York, Mahwah, NJ.

Spears, L.C., 2004, 'The understanding and practice of servant-leadership', in L.C. Spears \& M. Lawrence (eds.), Practicing servant leadership: Succeeding through trust, bravery, and forgiveness, pp. 9-24, Jossey-Bass School of Leadership Studies, Regent University, Virginia Beach, VA.

Spears, L.C., 2010, 'Servant leadership and Robert K. Greenleaf's legacy', in D. Van Dierendonck \& K. Patterson (eds.), Servant leadership, pp. 11-24, Palgrave Macmillan, London.

Stanley, D.,1961, 'I am the good shepherd', Worship 35(5), 287-293.

Swalm, J.E., 2010, 'The development of shepherd leadership theory and the validation of the shepherd leadership inventory (SLI)', 3-203, Doctoral dissertation, Regent University, Virginia Beach, VA, viewed 20 June 2019, from https://search.

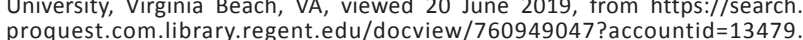
proquest.co
(760949047).

Tenney, M.C., 1975, John - The gospel of belief: An analytical study of the text, Wm. B. Eerdmans Publishing, Grand Rapids, MI.

Tenney, M.C., 1981, 'John', in F.E. Gaebelein (ed.), The expositor's Bible commentary, vol. 9, pp. 3-203, Zondervan, Grand Rapids, MI.

Thompson, F.M., 2007, Identifying and developing leaders: A biblical, historical and theological perspective, Xulon Press, Maitland, FL.

Wessels, W.J., 2014, 'Leader responsibility in the workplace: Exploring the shepherd metaphor in the book of Jeremiah', Koers - Bulletin for Christian Scholarship 79(2), Art.\# 2121. https://doi.org/10.4102/koers.v79i2.2121

Wheatley, M., 2002, The servant leader: From hero to host (book 7), The Greenleaf Center for Servant Leadership, Indianapolis, IN.

Wiersbe, W.W., 1991, The integrity crisis, Thomas Nelson Publishers, Nashville, TN.

Witmer, T.Z., 2010, The shepherd leader: Achieving effective shepherding in your church, P\&R Publishing, Phillipsburg, NJ.

Wong, P.T.P., 2007, 'Best practices in servant leadership', Servant Leadership Research Roundtable - July 2007, School of Global Leadership \& Entrepreneurship, Regent University, Virginia Beach, VA.

Wright, W.M., 2012, 'Hearing the shepherd's voice: The proverb of the good shepherd discourse and Augustine's figural reading', Journal of Theological Interpretation 6(1), 97-116. 